\title{
Pott's Puffy Tumor in an Adult: A Case Report and Review of Literature
}

\author{
Satomi Tatsumi ${ }^{1}$, Min $\mathrm{Ri}^{1}$, Naoyuki Higashi ${ }^{1}$, \\ Nozomu Wakayama², Shoji Matsune ${ }^{2}$ and Mamiko Tosa ${ }^{3}$ \\ ${ }^{1}$ Department of Dermatology, Nippon Medical School Tama Nagayama Hospital, Tokyo, Japan \\ ${ }^{2}$ Department of Otolaryngology, Nippon Medical School Musashi Kosugi Hospital, Kanagawa, Japan \\ ${ }^{3}$ Department of Plastic and Reconstructive Surgery, Nippon Medical School Musashi Kosugi Hospital, Kanagawa, Japan \\ Pott's puffy tumor is a subperiosteal abscess of the frontal bone with osteomyelitis which has become \\ rare because of the widespread use of antibiotics. Here, we report a case of Pott's puffy tumor in a 46- \\ year-old man who visited the department of dermatology with painful swelling of the forehead. De- \\ spite open drainage and oral antibiotic therapy, the symptoms recurred twice in the following month. \\ Computed tomography revealed a fistula of frontal bone. The eventual diagnosis was Pott's puffy tu- \\ mor. The patient underwent endoscopic surgery at the department of otorhinolaryngology and achieved \\ a complete recovery. (J Nippon Med Sch 2016; 83: 211-214)
}

Key words: Pott's puffy tumor, sinusitis, epidermal cyst, osteomyelitis

\section{Introduction}

Pott's puffy tumor (PPT) is a subperiosteal abscess of the frontal bone and is associated with osteomyelitis. This condition is usually observed in adolescents and is therefore considered rare in adults ${ }^{1}$. We present a case of PPT in an adult patient.

\section{Case Report}

A 46-year-old man presented to the department of dermatology of the Nippon Medical School Tama Nagayama Hospital with painful swelling of the forehead which had first appeared 6 months earlier and had occurred repeatedly in the same location. He had no history of trauma or surgery.

Physical examination revealed a $4 \mathrm{~cm}$ diameter, soft, tender, well-demarcated area of swelling with pulsation at the center of the forehead (Fig. 1). There were no neurological symptoms or symptoms, such as vomiting, indicating increased intracranial pressure.

Computed tomography (CT) examination of the head showed a subcutaneous cyst with fluid collection in the forehead (Fig. 2). Because an infection of an epidermal cyst was possible, incisional drainage was performed and resulted in a large amount of bloody pus being discharged. The swelling decreased after systemic admini- stration of the antibiotic cefcapene pivoxil. Bacterial culture of pus revealed no organism. The swelling of the forehead recurred twice during the subsequent month and required incisional drainage again. Therefore, magnetic resonance imaging (MRI) of the head was performed to exclude disorders other than an epidermal cyst. A cystic lesion in the left ethmoid sinus showed low intensity in T1-weighted images and high intensity in T2weighted images (Fig. 3).

Considering the possibility of inflammation in the left

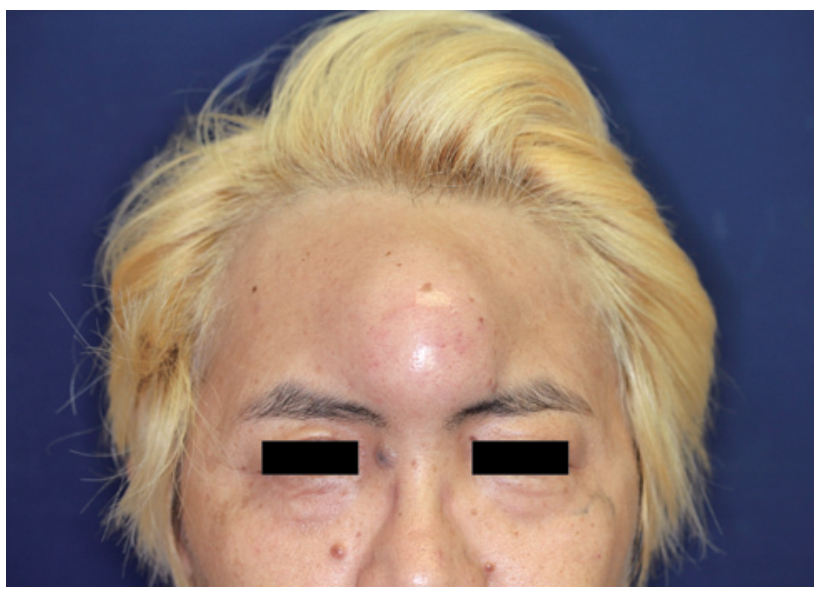

Fig. 1 Clinical image showing a soft, well-demarcated swelling protruding from the frontal lesion.

Correspondence to Satomi Tatsumi, MD, PhD, Department of Dermatology, Nippon Medical School Tama Nagayama Hospital, 1-7-1 Nagayama, Tama, Tokyo 206-0025, Japan

E-mail: syama@nms.ac.jp

Journal Website (http://www.nms.ac.jp/jnms/) 

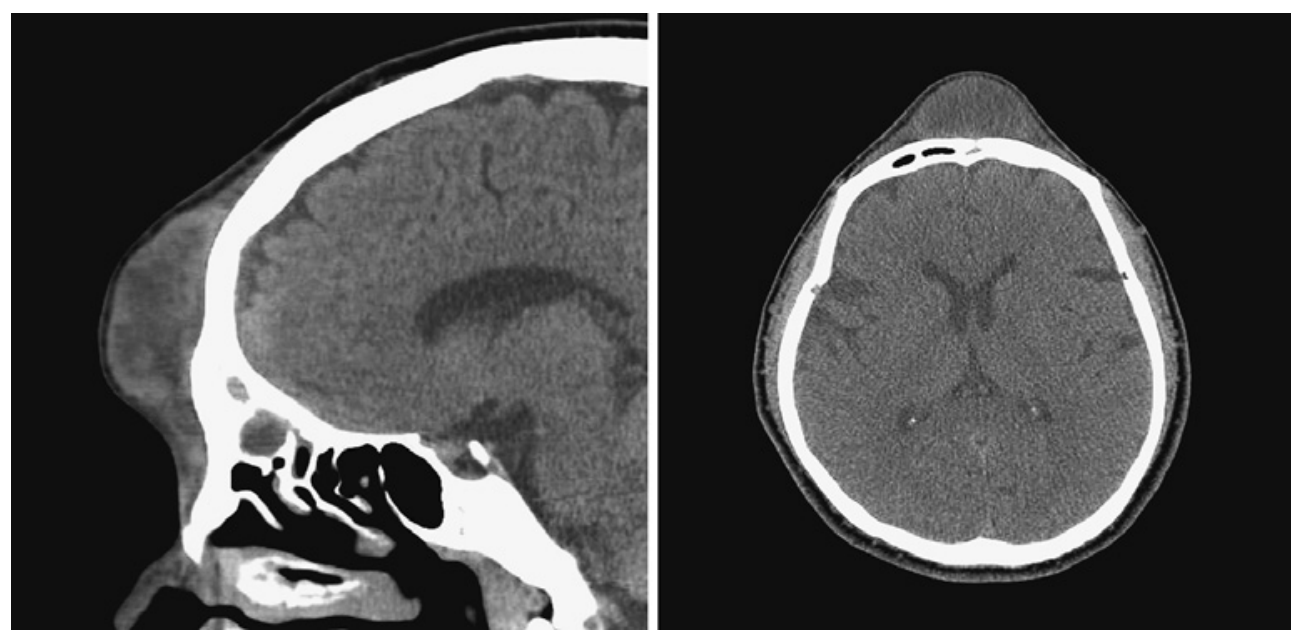

Fig. 2 Computed tomography images. Axial and sagittal slices showing a subcutaneous cyst with fluid collection in the forehead.
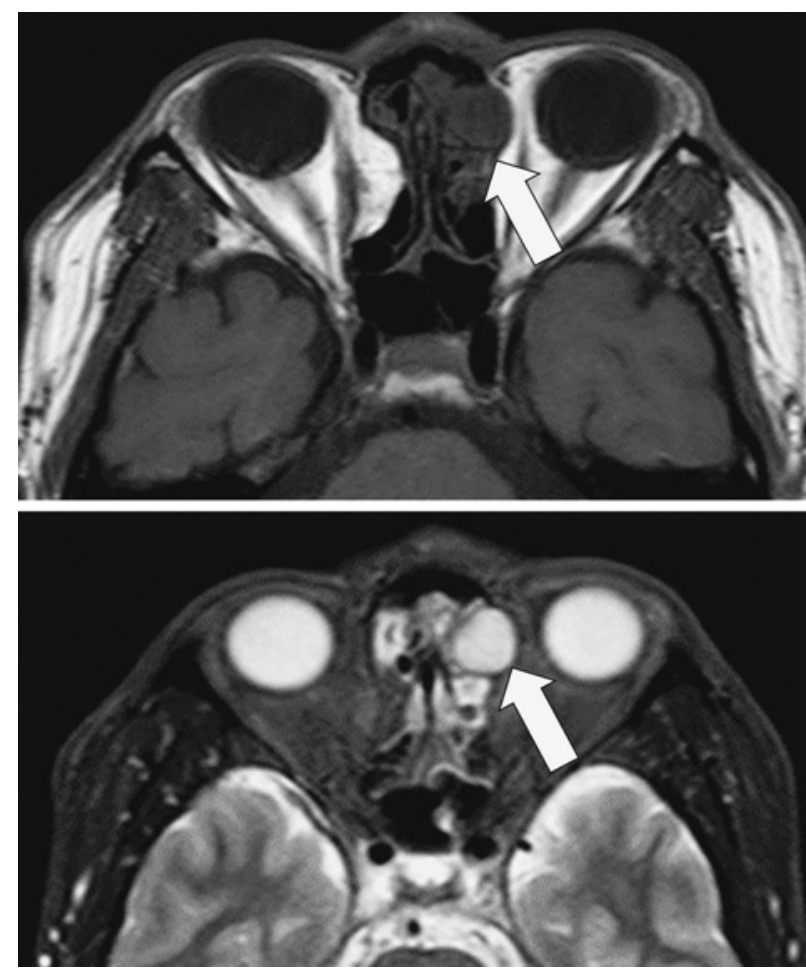

Fig. 3 Magnetic resonance imaging showing a cystic lesion in the left ethmoid sinus (arrows).

ethmoid sinus extending to the forehead, we reexamined the computed tomographic images of the head and found a hole bone defect in the anterior wall of the frontal sinus and a collection of fluid in the frontal sinus (Fig. 4). Thus, we assumed that the inflammation had spread to the subcutaneous tissue through a fistula in the frontal bone via the paranasal sinuses. On the basis on these findings, we consulted with the department of plastic surgery at our hospital and the department of

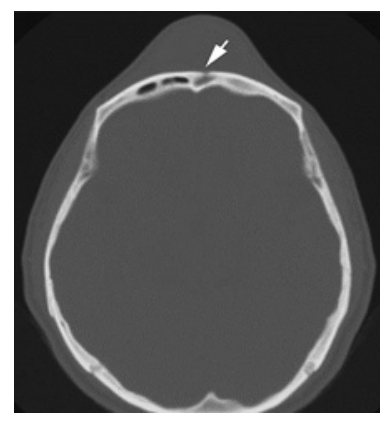

Fig. 4 Computed tomography image. A bone window, showing a bone defect in the anterior wall of the frontal sinus and fluid collection in the frontal sinus (arrow).

otorhinolaryngology of the Nippon Medical School Musashi Kosugi Hospital, and diagnosed PPT. The patient underwent endoscopic sinus surgery at the department of otorhinolaryngology. He has had no recurrence of PPT thereafter.

\section{Discussion}

The subperiosteal abscess known as PPT is formed by inflammation in the frontal sinus via a fistula in the frontal bone $^{1}$. Sir Percivall Pott first reported this disorder in 1,768 as "a subperiosteal abscess in the forehead resulting from a trauma." He subsequently reported that this disorder resulted from frontal sinusitis ${ }^{2}$.

Worsening of frontal sinusitis is believed to cause osteomyelitis of the frontal bone, resulting in a fistula, through which inflammation spreads under the skin ${ }^{3}$. Intracranial complications such as epidural, subdural and brain abscess may accompany $\mathrm{PPT}^{4}$. 
Because PPT commonly occurs in young people, it is considered to result from (1) an anatomically undeveloped frontal sinus and (2) increased blood flow in the diploic veins in adolescence ${ }^{1,5}$. The diploic veins are distributed between the external and internal tables of the calvaria. Because the veins in the frontal sinus mucosa run to the dural venous plexus via the diploic veins, they are believed to be a pathway for intracranial infection ${ }^{4}$. In addition, PPT is more common in male, and the male : female ratio has been reported to be approximately $3: 1^{6}$. However, the reasons for this difference are unclear ${ }^{6}$.

The differential diagnosis of PPT includes hematoma, skin and soft-tissue infections, and soft-tissue tumors ${ }^{7}$. Common causative bacteria are staphylococci, such as Staphylococcus aureus and Staphylococcus epidermis. Anaerobic bacteria are occasionally detected in cases of exacerbation from a carious tooth ${ }^{8}$.

In most patients PPT is treated with a systemic antibiotic agent effective against the causative bacteria and with percutaneous or transnasal drainage ${ }^{1}$. Debridement is performed if an artificial substance or a sequestrum is present in the wound. Craniotomy might be required if PPT is accompanied by an intracranial lesion, such as brain and epidural abscess ${ }^{9}$.

Cases of PPT in adults are rarely reported. Literature searches with PubMed, Ichushi Web by the Japan Medical Abstracts Society, and Google Scholar found a total of 54 adult patients with PPT, including the present patient, reported on in Japanese or English to date until $2015^{1,4,10-29}$. These adult patients were 42 men and 12 women (male : female ratio, $3.5: 1$ ), ranged in age from 20 to 83 years, and had a mean age of 44.9 years. The percentage of all patients with intracranial complications, such as a brain abscess, was $27.8 \%$, which was less than the $60 \%$ to $85 \%$ in previous studies including children ${ }^{8}$. The underlying diseases included conditions associated with increased susceptibility to infection, such as diabetes mellitus, receiving dialysis, and aplastic anemia ${ }^{1}$. In addition, PPT in adults have been associated with intranasal cocaine or methamphetamine abuse $\mathrm{e}^{1,11}$. Cocaine is believed to increase the susceptibility of local tissues to infection $^{30}$. Although some patients had a history of open skull fracture due to traffic accidents, several other patients had PPT resulting from a minor trauma caused by an insect bite or the forehead hitting a door ${ }^{1}$. Old trauma also requires attention. One adult patient had undergone craniotomy in his youth, been infected with human immunodeficiency virus 13 years later, and became susceptible to infection, resulting in $\mathrm{PPT}^{26}$.
The present patient had no noteworthy history, including a history of trauma. The CT and MRI images showed a cystic lesion in the ethmoid sinus; therefore, we considered two possible processes by which PPT developed: (1) progression to PPT because of exacerbation of ethmoidal sinusitis and (2) repeated minor traumas, such as scratching associated with frequently wearing a helmet as a construction worker.

Because we initially suspected that the present patient had a secondary infection of an epidermal cyst, we did not make a confirmed diagnosis of PPT until approximately 4 months later. Early diagnosis is desirable, because intracranial complications can be fatal ${ }^{4}$. Patients first examined by an otorhinolaryngologist have been reported to more often receive a correct diagnosis of PPT and to less often have intracranial complications than do patients first examined by physicians of other departments, including dermatology ${ }^{1}$. We examined the present adult patient and, because of our lack of correct background knowledge, were unable to correctly diagnosis PPT at an early stage. Although PPT is rare, clinicians should quickly work with other departments and consider the possibility of PPT if swelling repeatedly occurs in a patient's forehead.

Conflict of Interest: The authors declare no conflict of interet.

\section{References}

1. Akiyama K, Karaki M, Mori N: Evaluation of adult pott's puffy tumor: Our five cases and 27 literature cases. Laryngoscope 2012; 122: 2382-2388.

2. Tattersall R: Pott's puffy tumor. Lancet 2002; 359: 10601063.

3. Akiyama K, Karaki M, Takeda J, Mori N: Two cases report of pott's puffy tumor and pott's puffy like tumor. The Journal of Japan Rhinologic Society 2011; 50: 143-150 (in Japanese).

4. Ketenci İ, Ünlü Y, Tucer B, Vural A: The Pott's puffy tumor: a dangerous sign for intracranial complications. Eur Arch Oto-Rhino-Laryngology 2011; 268: 1755-1763.

5. Weinberg B, Gupta S, Thomas MJ, Stern H: Pott's puffy tumor: Sonographic diagnosis. J Clin Ultrasound 2005; 33: 305-307.

6. Nisa L, Landis BN, Giger R: Orbital involvement in Pott's puffy tumor: a systematic review of published cases. Am J Rhinol Allergy 2014; 26: e63-70.

7. Bellaney GJ, Ryan TJ: Pott's puffy tumour. Br J Dermatol 1997; 136: 145-147.

8. Chandy B, Todd J, Stucker FJ, Nathan CA: Pott's puffy tumor and epidural abscess arising from dental sepsis: a case report. Laryngoscope 2001; 111: 1732-1734.

9. Kombogiorgas D, Solanki GA: The Pott puffy tumor revisited: neurosurgical implications of this unforgotten entity - Case report and review of the literature. J Neurosurg 2006; 105: 143-149.

10. Babu R, Todor R, Kasoff S: Pott's puffy tumor: the forgot- 
ten entity: Case report. J Neurosurg 1996; 84: 110-112.

11. Banooni P, Rickman L, Ward D: Pott puffy tumor associated with intranasal methamphetamine. JAMA 2000; 283: 1293.

12. Chow K, Szeto C: Headache caused by Pott's puffy tumor. Headache 2003; 43: 916.

13. Adejumo A, Ogunlesi O: Pott puffy tumor complicating frontal sinusitis. Am J Med Sci 2010; 340: 79.

14. Upadhyay S: Recurrent Pott's puffy tumor, a rare clinical entity. Neurol India 2010; 58: 815-817.

15. Olaleye O, Fu B, Sharp H: Recurrent Pott's puffy tumour. BMJ Case Rep 2011; bcr1220103649.

16. Acke E, Lemmerling M: Pott's puffy tumor: CT and MRI findings. J Belge Radiol 2011; 94: 343-345.

17. Umezawa K, Branch J, Hasegawa K: Facial swelling. Ann Emerg Med 2012; 59: 234-238.

18. Elyassi A, Prenzel R, Closmann J: Pott puffy tumor after maxillary tooth extraction. J Oral Maxillofac Surg 2012; 70: e190-e192.

19. Welch E, Kwong F, Mohammed H, Cathcart R: An unusual swelling of the forehead. N Z Med J 2012; 125: 8891.

20. Sullivan C, Poetker D: Anterior table remodeling after treatment for Pott's puffy tumor. Am J Otolaryngol 2013; 34: 265-267.

21. Rajwani K, Desai K, Lew-Gor S: Forehead swelling and frontal headache: Pott's puffy tumour. BMJ Case Rep 2014; bcr2013202737.

22. Williams S, Wilkie M: Pott's puffy tumour: an unforgettable complication of frontal sinusitis. BMJ Case Rep 2014; bcr2014204061.
23. ur Rehman A: Pott puffy tumor: a rare complication of sinusitis. Ann Saudi Med 2013; 33: 79-80.

24. Domville-Lewis C, Friedland PL, Santa Maria PL: Pott's puffy tumour and intracranial complications of frontal sinusitis in pregnancy. J Laryngol Otol 2012; 127 (April 2012): 1-4.

25. Ciobanu A, Roşca T, Vlădescu C: Frontal epidural empyema (Pott's puffy tumor) associated with Mycoplasma and depression. Rom J Morphol Embryol 2014; 55: 12031207.

26. Ibrahim S, Al-Saffar F: Potts puffy tmor: a new complication of HIV. J Gen Pract 2014; 2: 154.

27. Hashimoto H, Horie S, Takase K, Kashihara M, Okada S, Kimoto A, Korai H: Chronic intracranial epidural abscess with Pott's puffy tumor. A case report. Tokushima J Med 1994; 16: 61-69 (in Japanese).

28. Mizuyoshi Y, Nomura T, Masuda K, Nagafune H, Unoki S, Komatsuzaki A: A case of frontal sinusitis accompanied by osteolysis of frontal bone. Otolaryngology 1985; 57: 389-393 (in Japanese).

29. Yokoji H, Ohta H, Nakamura S, Ikeda T: MRI findings of Pott's puffy tumor in a chronic hemodialysis patient. Neurological Medicine 1997; 46: 209-210.

30. Rubin K: The manifestation of cocaine-induced midline destructive lesion in bone tissue and its identification in human skeletal remains. Forensic Sci Int 2013; 231: 408 e1-11.

(Received, May 20, 2016)

(Accepted, October 3, 2016) 